\title{
RESPON PERTUMBUHAN DAN HASIL JAMUR TIRAM PUTIH (Pleurotus ostreatus) TERHADAP SUBTITUSI SEKAM PADI DAN PEMBERIAN SUPLEMEN ORGANIK
}

\author{
(Growth Response And Yield Of White Oyster Mushroom(Pleurotus ostreatus) to Rice Husk \\ Substitution And Organic Supplement)
}

\author{
Malik Tsaqafi, Darso Sugiono, Ani Lestari \\ Program Studi Agroteknologi, Fakultas Pertanian, Universitas Singaperbangsa Karawang \\ J1. HS Ronggowaluyo, Teluk Jambe Timur, Kab. Karawang \\ Penulis koresponden : tsaqafiaka@gmail.com
}

Article Submitted: 23-07-2021

Article Accepted: 03-08-2021

\begin{abstract}
White oyster mushroom (Pleurotus ostreatus) is a type of local mushroom that has been and is being developed in Indonesia. Efforts to find alternative media for sawdust if it is difficult to obtain or not available and the addition of nutrients from the outside by giving organic supplements to increase the growth and development of oyster mushrooms. The experiment was carried out in Bahagia Village, Babelan District, Bekasi Regency. The research method used was an experimental method with a single factor Randomized Block Design (RBD). There were 10 treatment, namely A (without the addition of media + aquades 100\%), B (15\% rice husk $+25 \%$ organic supplement), C (15\% rice husk $+50 \%$ organic supplement), D (15\% rice husk $+75 \%$ organic supplement), E (30\% rice husk $+25 \%$ organic supplement), F (30\% rice husk $+50 \%$ organic supplement), $\mathrm{G}(30 \%$ rice husk $+75 \%$ organic supplement), $\mathrm{H}$ ( $45 \%$ rice husk $+25 \%$ organic supplement), I (45\% rice husk $+50 \%$ organic supplement) and $\mathrm{J}$ (45\% rice husk $+75 \%$ organic supplement). The results showed that there was a significant effect of rice husk substitution and organic supplementation on the number of fruit clumps per baglog, fruit cap diameter per baglog, and fresh weight of mushrooms per baglog. Treatment C (15\% rice husk + $50 \%$ organic supplement) gave the highest results on the parameters of the number of fruit clumps per baglog (1.00), fruit cap diameter per baglog $(6.03 \mathrm{~cm})$, fresh weight of mushrooms per baglog (60.54 grams).
\end{abstract}

Keywords: white oyster mushroom, rice husk, organic supplement

\section{PENDAHULUAN}

Jamur tiram puth (Pleurotus ostreatus) ialah jamur pangan yang sangat populer. Jenis jamur lokal yang telah dan sedang dikembangkan di Indonesia sebagai sumber makanan kaya nutrisi (Kadir, 2010). Permintaan jamur tiram putih semakin meningkat setiap tahunnya. Diluar kebutuhan luar negeri, produksen lokal jamur tiram hanya dapat memenuhi sebagian dari kebutuhan domestik (Nugraha, 2015). Keadaan ini menunjukkan bahwa peluang pasar budidaya jamur masih sangat terbuka, dan permintaan dapat meningkat. Media tanam ialah salah satu faktor penting dalam menentukan berhasil tidaknya budidaya jamur tiram. Serbuk kayu pada umumnya digunakan sebagai media jamur tiram. Jika potensi lahan hutan semakin berkurang dan dibatasi, hal ini dapat menimbulkan konsekuensi berupa serbuk kayu yang sulit diperoleh. Upaya mengantisipasi kebutuhan serbuk kayu tersebut dengan mencari bahan pengganti 
yang siap diolah serta mudah ditemukan. Limbah pertanian merupakan bahan alternatif dalam mensubtitusi serbuk kayu pada media tanam (Hariadi et al. 2013).

Sekam padi dipergunakan menjadi bahan tambahan untuk media tanam jamur tiram putih dikarenakan mudah diperoleh serta nutrisi yang terkandung di dalamnya diperlukan untuk pertumbuhan jamur tiram putih (Ikhsan dan Ariani, 2017). Sekam padi ialah limbah yang memiliki kandungan serat dengan komponen utamanya yaitu 19$47 \%$ lignin, $13 \%$ silika, $33-44 \%$ selulosa, dan 17-26\% hemiselulosa (Sipahutar 2010). Menurut Suparti dan Marfuah (2015), dalam penelitiannya menyatakan bahwa penggunaan sekam padi $15 \%$ pada media baglog mampu meningkatkan rata-rata bobot segar jamur tiram putih. Kemudian Rosnina et al. (2017), menyebutkan bahwa sekam padi mempengaruhi diameter tudung buah jamur tiram putih.

Sehubungan dengan masih terbatasnya penggunaan unsur hara pada media budidaya dasar jamur tiram maka perlu dilakukan penambahan unsur hara dari luar agar mampu meningkatkan pertumbuhan dan perkembangannya. Jamur membutuhkan unsur hara untuk tumbuh dan berkembang dalam bentuk unsur kimia seperti nitrogen, kalium, karbon dan fosfor (Suriawira, 2002). Menurut Rahma et al. (2016) diameter tudung dipengaruhi oleh nitrogen yang merupakan sumber protein penting dan komponen jaringan yang sedang aktif tumbuh.

Penambahan suplemen organik yang mengandung banyak unsur seperti Nitrogen, $\mathrm{Fe}, \mathrm{P}_{2} \mathrm{O}_{5}, \mathrm{Cu}, \mathrm{K}_{2} \mathrm{O}, \mathrm{SO}_{4}, \mathrm{Mg}, \mathrm{Zn}, \mathrm{PH}, \mathrm{C}$, Mo dan karbon organik untuk meningkatkan produksi jamur dan dapat mempercepat masa panen serta dapat memenuhi kebutuhan nutrisi jamur tiram dalam perkembangannya sehari-hari. Berdasarkan penelitian sebelumnya yang dilakukan oleh Wahyuning (2019) menyatakan bahwa perlakuan dengan konsentrasi suplemen organik dan air 25\% :
75\% menunjukkan bahwa penambahan suplemen organik berpengaruh pada peningkatan hasil berat basah jamur tiram putih sehingga menghasilkan produktivitas jamur tiram paling optimal. Oleh karena itu, pada penelitian ini perlunya dilakukan peningkatan kandungan sekam padi dalam media tumbuh dan peningkatan konsentrasi pemberian suplemen organik terhadap jamur tiram putih. Penelitian ini diharapkan dapat mengetahui subtitusi media sekam padi yang memberikan hasil tertinggi untuk tiap suplemen organik terhadap pertumbuhan dan hasil jamur tiram putih (Pleurotus ostreatus)

\section{METODE PENELITIAN}

\section{Waktu dan Tempat}

Penelitian dilakukan di Desa Bahagia, Kecamatan Babelan, Kabupaten Bekasi. Berada pada titik kordinat $6^{\circ} 11^{\prime}$ 40,9' ' LU dan $107^{\circ} 01$ ' $0,27^{\prime}$ ' BT. Berlangsung dari bulan Maret sampai Mei 2021.

\section{Bahan dan Alat}

Bahan yang digunakan dalam penelitian ini yaitu bibit jamur tiram putih F3 berasal dari petani jamur di Bekasi, sekam mentah padi, suplemen organik tanaman yang diproduksi oleh CV. HCS Powerindo, serbuk kayu, bekatul, pupuk TSP murni, kapur pertanian, gas, aquades, desinfektan, dan alkohol $70 \%$.

Alat yang digunakan yaitu Thermohygrometer, hand sprayer, drum untuk sterilisasi, timbangan digital, gelas ukur $500 \mathrm{ml}$, jangka sorong, dan cutter.

\section{Rancangan Penelitian}

Penelitian ini menerapkan metode eksperimen dengan Rancangan Acak Kelompok (RAK) faktor tunggal dengan 10 perlakuan dan 3 kali ulangan. Terdapat 10 perlakuan, yaitu A (tanpa penambahan media + aquades 100\%), B (sekam padi $15 \%+$ suplemen organik $25 \%$ ), C (sekam padi $15 \%$ + suplemen organik $50 \%$ ), D (sekam padi $15 \%+$ suplemen organik 
75\%), E (sekam padi 30\% + suplemen organik 25\%), F (sekam padi $30 \%+$ suplemen organik $50 \%$ ), G (sekam padi $30 \%+$ suplemen organik $75 \%$ ), H (sekam padi $45 \%+$ suplemen organik $25 \%$ ), I (sekam padi $45 \%+$ suplemen organik $50 \%$ ) dan $\mathrm{J}$ (sekam padi $45 \%$ + suplemen organik $75 \%$ ). Apabila rerata hasil uji $\mathrm{F}$ taraf $5 \%$ menunjukkan hasil yang signifikan, maka akan dilakukan uji lanjut Duncan Multiple Range Test (DMRT) pada taraf 5\% (Gomez dan Gomez 2010).

\section{Prosedur Pene litian}

1. Pembuatan dan Sterilisasi Media Tanam

Sekam padi digiling terlebih dahulu dengan penggiling untuk mendapatkan sekam $0,8 \mathrm{~mm}$. Semua bahan media tanam ditimbang sesuai dengan komposisi tiap perlakuan. Kemudian aduk rata, tambahkan air sampai kadar air 60\% atau ketika media digenggam dengan tangan mengepal, media tidak pecah (Zulfarina et al. 2019). Kemudian media yang telah tercampur rata dilakukan pengomposan selama 3 (tiga) hari. Setelah proses fermentasi hingga $\mathrm{pH}$ pada media antara 7-8 kemudian dimasukkan ke dalam kantong plastik polipropilen (PP) dengan berat total media tanam yaitu $1000 \quad \mathrm{~g}$.

Sterilisasi media dengan menggunakan steamer dari drum bekas selama 10-14 jam dengan suhu yang dijaga kisaran $100^{\circ} \mathrm{C}$ untuk memperkecil prosentasi kegagalan sterilisasi baglog (Wibisono, 2014). Media yang sudah disterilisasikan kemudian didinginkan selama 8-12 jam dalam ruangan hingga mencapai suhu ruangan 28 $-30^{\circ} \mathrm{C}$.

2. Inokulasi dan Inkubasi

Inokulasi dilakukan dengan memasukkan bibit jamur tiram puth F2 sebanyak $10 \mathrm{~g}$ ke dalam baglog mengunakan spatula. Baglog yang sudah dimasukkan bibit selanjutnya ditutup menggunakan cincin baglog. Setelah langkah inokulasi dilakukan, tahap selanjutnya adalah inkubasi baglog ke dalam ruangan dengan suhu $27-30^{\circ} \mathrm{C}$ dengan kelembapan 60-70\% (Zulfarina et al. 2019).

3. Pembuatan dan Aplikasi Nutrisi

Suplemen organik dilarutkan dengan 1,5 liter air atau 1 : 1500. Selanjutnya campuran suplemen organik dan air tersebut kemudian diberi 1 sendok makan gula pasir yang berfungsi untuk mengaktifkan kerja bakteri yang terdapat pada suplemen organik. Kemudian dilakukan pembuatan larutan nutrisi perlakuan sesuai dengan konsentrasi yang sudah ditentukan. Aplikasi suplemen organik dilakukan setiap hari selama satu periode tanam (6 minggu). dengan cara menyemprotkan suplemen organik dengan menggunakan hand sprayer pada baglog jamur tiram setelah proses inkubasi selesai dilakukan (plastik penutup baglog telah dibuka). Aplikasi dilakukan sebanyak 4 kali semprotan dengan volume semprot $\pm 4 \mathrm{ml}$ pada setiap baglog. (Wahyuning 2019).

4. Pemeliharaan

Pemeliharaan dengan cara mengatur suhu kumbung dengan melakukan pengkabutan dengan air pada lantai dan dinding kumbung menggunakan hand sprayer. Hal ini bertujuan untuk mengembalikan kondisi optimal iklim mikro kumbung jamur. Penyiraman dilakukan setiap hari pada pagi dan sore hari.

\section{Variabel Pengamatan}

1. Jumlah Rumpun per Baglog

Pengamatan dilakukan pada saat panen dengan cara menghitung keseluruhan jumlah rumpun buah yang tumbuh dalam setiap baglog jamur tiram putih. Kemudian dihitung rata-rata jumlah rumpun buah pada setiap perlakuan dan ulangan dalam satu periode (6 minggu).

2. Jumlah Tudung Buah per Rumpun

Pengamatan dilakukan pada saat panen dengan cara menghitung jumlah tudung buah yang tumbuh dalam satu rumpun jamur tiram putih. Kemudian dihitung ratarata jumlah tudung buah pada setiap perlakuan dan ulangan dalam satu periode 
(6 minggu).

3. Diameter Tudung Buah Maksimal per Baglog

Pengamatan pada diameter tudung buah maksimal per baglog dilakukan pada saat panen dengan cara mengukur diameter tudung buah jamur tiram puth yang terbesar menggunakan jangka sorong dalam satuan Panjang $(\mathrm{cm})$

4. Bobot Segar per Bgalog

Perhitungan bobot segar jamur per baglog dilakukan saat jamur tiram putih telah dipanen dengan menimbang keseluruhan rumpun dalam satuan berat $(\mathrm{g})$. Kemudian dihitung rata-rata bobot segar pada setiap perlakuan dan ulangan dalam satu periode (6 minggu).

\section{HASIL DAN PEMBAHASAN}

\section{Jumlah Rumpun Buah Per Baglog}

Pada perlakuan C (sekam padi $15 \%$ + suplemen organik 50\%) menunjukkan rata-rata jumlah rumpun tertinggi yaitu 1,00 buah berbeda nyata dengan perlakuan $\mathrm{E}$ (sekam padi $30 \%+$ suplemen organik $25 \%$ ) dengan rerata $0,53, \mathrm{~F}$ (sekam padi $30 \%+$ suplemen organik $50 \%$ dengan rerata 0,59 , $\mathrm{G}$ (sekam padi $30 \%$ + suplemen organik $75 \%$ dengan rerata 0,61 , dan $\mathrm{H}$ (sekam padi $45 \%+$ suplemen organik $25 \%$ ) dengan rerata 0,31 .

Hal ini berkorelasi dengan pengamatan pemenuhan miselium. Sejalan dengan Chang dan Miles (2004), yang menyatakan bahwa badah buah akan mucul lebih cepat jika diirngi dengan perkembangan miselium yang baik.

Nutrisi tambahan juga harus memenuhi kebutuhan nutrisi pada jamur antara lain protein, kalium, dan nitrogen. Suplemen organik dapat digunakan sebagai nutrisi organik karena mengandung nitrogen serta kalium. Menurut Rosnina et al. (2017) pembentukan dan perkembangan tubuh buah dipengaruhi oleh kalium sehingga kemungkinan pembentukan pin head menjadi lebih baik.

Tabel 1. Rata-rata Jumlah Rumpun Buah per Baglog

\begin{tabular}{clc}
\hline \multirow{2}{*}{ Kode } & \multicolumn{1}{c}{ Perlakuan } & $\begin{array}{c}\text { Jumlah Rumpun per Baglog } \\
\text { (buah) }\end{array}$ \\
\hline A & Tanpa penambahan media + Aquades 100\% & $0,69 \mathrm{ab}$ \\
B & Sekam Padi 15\% + Suplemen Organik 25\% & $0,83 \mathrm{ab}$ \\
C & Sekam Padi 15\% + Suplemen Organik 50\% & $1,00 \mathrm{a}$ \\
D & Sekam Padi 15\% + Suplemen Organik 75\% & $0,83 \mathrm{ab}$ \\
E & Sekam Padi 30\% + Suplemen Organik 25\% & $0,53 \mathrm{bc}$ \\
F & Sekam Padi 30\% + Suplemen Organik 50\% & $0,59 \mathrm{bc}$ \\
G & Sekam Padi 30\% + Suplemen Organik 75\% & $0,61 \mathrm{bc}$ \\
H & Sekam Padi 45\% + Suplemen Organik 25\% & $0,31 \mathrm{c}$ \\
I & Sekam Padi 45\% + Suplemen Organik 50\% & $0,80 \mathrm{ab}$ \\
J & Sekam Padi 45\% + Suplemen Organik 75\% & $0,75 \mathrm{ab}$ \\
\hline Keterangan: & Rata-rata yang ditandai dengan alfabet & serupa menunjukkan tidak terjadi \\
& perbedaan yang nyata menurut DMRT 5\%. &
\end{tabular}

Selain itu, jamur yang kurang mendapatkan penyinaran yang cukup akan berdampak pada rumpun. Menurut Istiqomah dan Fatimah (2014), jamur membutuhkan penyinaran dalam fase awal pembentukan buah, akan tetapi apabila jamur terkena penyinaran secara langsung dapat menyebabkan jamur menjadi layu.

\section{Jumlah Tudung Buah Per Rumpun \\ Pengamatan dilakukan dengan menghitung tudung buah yang terdapat}


pada setiap rumpun jamur tiram. Pada perlakuan C (sekam padi $15 \%$ + suplemen organik $50 \%$ ) menunjukkan rerata tertinggi yaitu 5,20 buah dan tidak berbeda nyata dengan perlakuan lainnya. perlakuan $\mathrm{H}$ menunjukkan rerata terendah yaitu 0,31 . Perkembangan tudung buah diduga dipengaruhi oleh banyaknya silika yang terkandung dalam sekam padi. Muchsin et al. (2017), pertumbuhan tudung buah yang tidak optimal disebebkan akumulasi silika yang terlampau tinggi sehingga sulit didegradasi oleh jamur tiram.

Melimpahnya sekam padi yang terkandung dalam media tanam jamur, maka perkembangan tudung buah tidak optimal. Menurut Marwah (2019), yang melaporkan bahwa pemberian sekam padi sebanyak $30 \%$ pada media tumbuh jamur tiram menunjukkan hasil tidak tidak terjadi ayang nyata dengan penambahan sekam padi $15 \%$ dan sekam padi $45 \%$.

Tabel 2. Rata-rata Jumlah Tudung Buah per Rumpun

\begin{tabular}{ccc}
\hline Kode & Perlakuan & $\begin{array}{c}\text { Jumlah Tudung Buah per Rumpun } \\
\text { (buah) }\end{array}$ \\
\hline A & Tanpa penambahan media + Aquades 100\% & $3,56 \mathrm{a}$ \\
B & Sekam Padi 15\% + Suplemen Organik 25\% & $4,34 \mathrm{a}$ \\
C & Sekam Padi 15\% + Suplemen Organik 50\% & $5,20 \mathrm{a}$ \\
D & Sekam Padi 15\% + Suplemen Organik 75\% & $5,11 \mathrm{a}$ \\
E & Sekam Padi 30\% + Suplemen Organik 25\% & $3,02 \mathrm{a}$ \\
F & Sekam Padi 30\% + Suplemen Organik 50\% & $3,44 \mathrm{a}$ \\
G & Sekam Padi 30\% + Suplemen Organik 75\% & $4,33 \mathrm{a}$ \\
H & Sekam Padi 45\% + Suplemen Organik 25\% & $2,87 \mathrm{a}$ \\
I & Sekam Padi 45\% + Suplemen Organik 50\% & $3,28 \mathrm{a}$ \\
J & Sekam Padi 45\% + Suplemen Organik 75\% & $3,98 \mathrm{a}$ \\
\hline
\end{tabular}

Keterangan : Rata-rata yang ditandai dengan alfabet yang sama menunjukkan bahwa tidak terdapat perbedaan yang nyata menurut DMRT 5\%.

Tudung buah diduga tidak tumbuh optimal disebabkan oleh suhu dan kelembaban kumbung yang fluktuatif. Menurut Arifin et al. (2014), tubuh buah tidak tumbuh secara optimal disebabkan suhu tinggi. Kenanga et al. (2014), menambahkan bahwa kelembapan udara bepengaruh terhadap pertumbuhan jamur tiram, badan buah jamur akan menguning serta kering apabila tidak sesuai dengan ketentuan kelembapan dan tudung buah akan menghadapi kendala absorpsi nutrisi sehingga menimbulkan kekeringan hingga kendala perkembangan ataupun kematian.

\section{Diameter Tudung Buah Maksimal Per Baglog}

Pada perlakuan C (sekam padi $15 \%$ + suplemen organik 50\%) memberikan diameter tudung buah tertinggi yaitu 6,03 $\mathrm{cm}$. Diameter tudung buah terendah diperoleh pada perlakuan $\mathrm{H}$ (sekam padi $45 \%+$ suplemen organik $25 \%$ ) yaitu 2,68 $\mathrm{cm}$. 
Tabel 3. Rata-rata Diameter Tudung Buah Maksimal per Baglog

\begin{tabular}{ccc}
\hline Kode & Perlakuan & $\begin{array}{c}\text { Diameter Tudung Buah Maksimal } \\
\text { per Baglog }(\mathrm{cm})\end{array}$ \\
\hline A & Tanpa penambahan media + Aquades 100\% & $4,70 \mathrm{ab}$ \\
B & Sekam Padi 15\% + Suplemen Organik 25\% & $5,47 \mathrm{ab}$ \\
C & Sekam Padi 15\% + Suplemen Organik 50\% & $6,03 \mathrm{a}$ \\
D & Sekam Padi 15\% + Suplemen Organik 75\% & $5,23 \mathrm{ab}$ \\
E & Sekam Padi 30\% + Suplemen Organik 25\% & $4,26 \mathrm{abc}$ \\
F & Sekam Padi 30\% + Suplemen Organik 50\% & $4,04 \mathrm{bc}$ \\
G & Sekam Padi 30\% + Suplemen Organik 75\% & $5,03 \mathrm{ab}$ \\
H & Sekam Padi 45\% + Suplemen Organik 25\% & $2,68 \mathrm{c}$ \\
I & Sekam Padi 45\% + Suplemen Organik 50\% & $4,13 \mathrm{bc}$ \\
J & Sekam Padi 45\% + Suplemen Organik 75\% & $4,58 \mathrm{ab}$ \\
\hline
\end{tabular}

Keterangan : Rata-rata yang ditandai dengan alfabet yang sama menunjukkan bahwa tidak terdapat perbedaan yang nyata menurut DMRT $5 \%$.

Hal ini diduga karena subtitusi sekam padi dan pemberian suplemen organik terhadap media tumbuh memberikan nutrisi yang cukup sehingga dapat meningkatkan diameter tudung buah jamur. Menurut Pokhrel et al. (2013), perkembangan tubuh buah tidak optimal jika terdapat kandungan selulosa dan lignin yang tingi didalam media tanam.

Sekam padi yang semakin banyak didalam media tanam akan mengandung banyak lignin. Berkaitan dengan pernyataan Amuneke et al. (2011), jika kandungan lignin dan selulosa dalam substrat tinggi, perkembangan tubuh buah tidak optimal. Menurut Wahyuning (2019), kandungan suplemen organik yang berfungsi dalam proses pembuatan tudung buah jamur tiram putih merupakan faktor $\mathrm{Zn}$ (Zinc) yang sanggup dimanfaatkan jamur tiram putih untuk mengaktifkan enzim yang akan menolong dalam proses metabolisme karbohidrat sehingga bisa mengoptimalkan absorpsi untuk pertumbuhan diamter tudung jamur tiram putih.

Tabel 4. Rata-rata Bobot Segar Jamur per Baglog

\begin{tabular}{ccc}
\hline Kode & Perlakuan & Bobot Segar per Baglog (gram) \\
\hline A & Tanpa penambahan media + Aquades 100\% & $35,08 \mathrm{bc}$ \\
B & Sekam Padi 15\% + Suplemen Organik 25\% & $50,79 \mathrm{ab}$ \\
C & Sekam Padi 15\% + Suplemen Organik 50\% & $60,54 \mathrm{a}$ \\
D & Sekam Padi 15\% + Suplemen Organik 75\% & $53,06 \mathrm{ab}$ \\
E & Sekam Padi 30\% + Suplemen Organik 25\% & $36,42 \mathrm{bc}$ \\
F & Sekam Padi 30\% + Suplemen Organik 50\% & $42,44 \mathrm{abc}$ \\
G & Sekam Padi 30\% + Suplemen Organik 75\% & $42,80 \mathrm{abc}$ \\
H & Sekam Padi 45\% + Suplemen Organik 25\% & $24,35 \mathrm{c}$ \\
I & Sekam Padi 45\% + Suplemen Organik 50\% & $32,70 \mathrm{bc}$ \\
J & Sekam Padi 45\% + Suplemen Organik 75\% & $34,46 \mathrm{bc}$
\end{tabular}

Keterangan: Rata-rata yang ditandai dengan alfabet yang sama menunjukkan bahwa tidak terdapat perbedaan yang nyata menurut DMRT $5 \%$. 


\section{Bobot Segar Jamur Per Baglog}

Pada perlakuan C (sekam padi 15\% + suplemen organik 50\%) memberikan ratarata bobot segar jamur tertinggi yaitu sebesar 60,54 gram bebeda nyata dengan perlakuan $\mathrm{H}$ (sekam padi $15 \%$ + suplemen organik $50 \%$ ) memberikan rata-rata bobot segar jamur terendah yaitu sebesar 24,35 gram.

Bobot segar jamur tiram dipengaruhi oleh jumlah tudung buah yang terbentuk sehingga semakin banyak tudung buah, semakin tinggi berat segar jamur. Menurut Nurafles (2015), apabila media tanam memiliki kandungan lignin, protein, selulosa, karbon, nitrogen, senyawa pati, oksigen, dan hidrogen, akan memungkinkan terpengaruhinya bobot segar jamur tiram putih

Pemberian media tanam padi serta pemberian suplemen organik pada media tumbuh diprediksi bisa penuhi kebutuhan nutrisi jamur tiram putih sehingga bisa menciptakan jumlah tudung buah serta bobot segar jamur yang besar. Menurut Wahyuning (2019), jamur tiram memerlukan nutrisi yang lebih banyak supaya kebutuhan hidupnya terus menjadi terjamin dengan metode pemberian suplemen organik yang diperlukan oleh jamur tiram putih seperti $\mathrm{N}$, $\mathrm{P}_{2} \mathrm{O}_{5}, \mathrm{~K}_{2} \mathrm{O}, \mathrm{SO}_{4}, \mathrm{Mg}$ serta karbon organik. Nutrisi yang ada pada media tanam bisa terdekomposisi secara menyeluruh sehingga jamur mempunyai cadangan tenaga yang bisa digunakan dalam proses pembuatan buah yang menciptakan bobot segar yang maksimal. Tidak hanya itu, aspek area berperan dalam perkembangan jamur yang mempengaruhi bobot segar jamur. Apabila suhu lingkungan rendah, maka dapat terjadi penguapan pada tudung buah jamur yang menyebabkan jamur menjadi kering dan mengkerut sehingga bobot segar jamur akan berkurang.

\section{KESIMPULAN DAN SARAN}

\section{Kesimpulan}

Sekam padi dan pemberian suplemen organik berpengaruh nyata pada jumlah rumpun buah per baglog, jumlah tudung buah per rumpun, diameter tudung buah per baglog, dan bobot segar jamur per baglog. Perlakuan C (sekam padi 15\% + suplemen organik 50\%) memberikan hasil tertinggi pada parameter jumlah rumpun buah per baglog (1,00 buah), diameter tudung buah per baglog $(6,03 \mathrm{~cm})$, bobot segar jamur per baglog $(60,54$ gram).

\section{Saran}

Subtitusi sekam padi $15 \%$ ditambah dengan pemberian suplemen organik 50\% dapat diaplikasikan para petani, pelaku bisnis dan mahasiswa pertanian yang akan membudidayakan jamur tiram untuk meningkatkan hasil produksi jamur tiram putih (Pleurotus ostreatus).

\section{UCAPAN TERIMAKASIH}

Penyusunan ini dapat terwujud karena bantuan dari banyak pihak, terkhusus bagi orang tua penulis, dan para Dosen Pembimbing serta civitas Fakultas Pertanian Universitas Singaperbangsa Karawang

\section{DAFTAR PUSTAKA}

Amuneke, E. H., Dike, K. S., \& Ogbulie, J. N. (2011). Cultivation of Pleurotus ostreatus : An edible mushroom from agro base waste products. $J$. Microbiol. Biotech. Res., 1(3), 1-14.

Arifin, I., Isnawati, \& Fitrihidajati, H. (2014). Penggunaan Limbah Kapas Industri Kain dengan Tambahan Bekatul sebagai Alternatif Bahan Media Tanam Jamur Tiram Puth (Pleurotus ostreatus). Lentera Bio, 3(3), 216-221.

Chang S.T dan P.G. Miles, 2004, Mushrooms cultivation, nutritional 
value, medicinal effect, and environmental impack Second Eddition. New York : CRC Press

Gomez, K.A., dan A.A. Gomez. (2010). Prosedur Statistik untuk Penelitian Pertanian. Terjemah Endang Sjamsudin dan Justika S. Baharsjah. , Jakarta : UI Press

Hariadi N, Setyobudi L, \& Nihayati E. (2013). Studi Pertumbuhan dan Hasil Produksi Jamur Tiram Puth (Pleorotus ostreatus) pada Media Tumbuh Jerami Padi dan Serbuk Gergaji. Jurnal Produksi Tanaman. Vol 1 (1):47-53.

Ikhsan, M., \& Ariani, E. (2017). Pengaruh Molase Terhadap Pertumbuhan dan Hasil Jamur Tiram Putih (Pleurotus ostreatus) pada Media Serbuk Kayu Mahang dan Sekam Padi. JOM, 4(2), 9-15.

Kadir, I. (2010). Pemanfaatan Iradiasi Untuk Memperpanjang Daya Simpan Jamur Tiram Putih (Pleurotus ostreatus) Kering. Jurnal Ilmiah Aplikasi Isotop Dan Radiasi, 6(1), 86-103.

Kenanga, P., A. Pambudi, \& R. L. Puspitasari. (2014). Perbandingan Pertumbuhan Jamur Tiram Putih di Kumbung Ciseeng dan Universitas Al-Azhar Indonesia. Jurnal Biologi 7 (2) : 94-98.

Marwah, H. (2019). Respons Pertumbuhan dan Hasil Jamur Tiram Puth (Pleurotus ostreatus) Akibat Penggunaan Media Sekam Padi dan Nutrisi Air Rebusan Tauge. Fakultas Pertanian Universitas Singaperbangsa Karawang.

Muchsin, A. Y, Murdiono, W.E \& Maghfoer, M.D, (2017). Pengaruh
Penambahan Sekam Padi Dan Bekatul Terhadap Pertumbuhan Dan Hasil Jamur Tiram Puth (Pleurotus ostreatus). Journal of Agricultural Science., 2(1): 30-38.

Nugraha, S. \& Setiawati, J. (2006). Peluang Bisnis Arang Sekam. Balai Penelitian Pascapanen Pertanian, Jakarta.

Nurafles, R. (2015). Pengaruh Komposisi Serbuk Gergajian Kayu dan Jerami Padi Terhadap Pertumbuhan dan Hasil Jamur Tiram Putih (Pleurotus ostreatus). Fakultas Pertanian Universitas Tamansiswa Padang.

Istiqomah, N. \& Fatimah, S. (2014). Pertumbuhan dan Hasil Jamur Tiram Pada Berbagai Komposisi Media Tanam. Ziraa'ah Majalah Ilmiah Pertanian Vol 39 (3) : 95-99.

Rahma, A., \& S. Purnomo. (2016). Pengaruh Campuran Ampas Tebu Dan Sabut Kelapa Sebagai Media Perrtumbuhan Alternatif Terhadap Kandungan Jamur Tiram (Pleurotus ostreatus). Jurnal Sains dan Seni ITS 5(2): 9092.

Rosnina, A. G., Wirda, Z., \& Aminullah, A. (2017). Efek Penambahan Sekam Padi Pada Berbagai media Tanam Terhadap Pertumbuhan dan Hasil Jamur Tiram Puth (Pleurotus ostreatus). Jurnal Agrium 14 (2) : 18 -25 .

Sharma, S., Yadav, R. K. P., \& Pokhrel, C. P. (2013). Growth and Yield of Oyster mushroom (Pleurotus ostreatus) on different substrates. Journal on New Biological Reports, 2(1), 3-8.

Sipahutar, D. (2010). Teknologi Briket 
Sekam Padi. Balai Pengkajian Teknologi Pertanian (BPTP), Riau.

Suparti \& L. Marfuah. (2015). Produktivitas Jamur Tiram Putih (Pleurotus oreatus) Pada Media Limbah Sekam Padi dan Daun Pisang Kering Sebagai Media Alternatif. Jurnal Bioeksperimen 1 (2) : 37-44.

Suriawiria, U. (2002). Budidaya Jamur Tiram. Yogyakarta: Penerbit Kanisius

Wahyuning, B. (2019). Pengaruh Penggunaan Suplemen Organik Di Berbagai Kosentrasi Untuk Meningkatkan Hasil Produksi Jamur Tiram Putih. Fakultas Ilmu Keguruan dan Ilmu Pendidikan Universitas Sanata Dharma.
Wibisono, S. \& Sudarsih. (2014). Ipteks Bagi Masyarakat Kelompok Usaha Baglog Jamur Tiram. Fakultas Ekonomi. Unversitas Jember.

Zulfarina, Z., E. Suryawati., Y. Yustina., R. A. Putra., dan H. Taufik. (2019). Budidaya Jamur Tiram dan Olahannya untuk Kemandirian Masyarakat Desa. Jurnal Pengabdian Kepada Masyarakat (Indonesian Journal of Community Engagement). 5(3): 358-370. 